\title{
Increases of Intracellular Magnesium Promote Glycodeoxycholate-induced Apoptosis in Rat Hepatocytes
}

\author{
Tushar Patel, Steven F. Bronk, and Gregory J. Gores \\ Center for Basic Research in Digestive Diseases, Division of Gastroenterology and Internal Medicine, Mayo Clinic and Mayo \\ Foundation, Rochester, Minnesota 55905
}

\begin{abstract}
Retention of bile salts by the hepatocyte contributes to liver injury during cholestasis. Although cell injury can occur by one of two mechanisms, necrosis versus apoptosis, information is lacking regarding apoptosis as a mechanism of cell death by bile salts. Our aim was to determine if the bile salt glycodeoxycholate (GDC) induces apoptosis in rat hepatocytes. Morphologic assessment included electron microscopy and quantitation of nuclear fragmentation by fluorescent microscopy. Biochemical studies included measurements of DNA fragmentation, in vitro endonuclease activity, cytosolic free $\mathrm{Ca}^{2+}\left(\mathrm{Ca}_{\mathrm{i}}^{2+}\right)$, and cytosolic free $\mathrm{Mg}^{2+}\left(\mathrm{Mg}_{\mathrm{i}}^{2+}\right)$. Morphologic studies demonstrated typical features of apoptosis in GDC ( $50 \mu \mathrm{M})$ treated cells. The "ladder pattern" of DNA fragmentation was also present in DNA obtained from GDC-treated cells. In vitro endonuclease activity was 2.5 fold greater with $\mathrm{Mg}^{2+}$ than $\mathrm{Ca}^{2+}$. Although basal $\mathrm{Ca}_{\mathrm{i}}{ }^{2+}$ values did not change after addition of $\mathbf{G D C}, \mathrm{Mg}_{\mathrm{i}}^{2+}$ increased twofold. Incubation of cells in an $\mathbf{M g}^{2+}$-free medium prevented the rise in $\mathrm{Mg}_{\mathrm{i}}^{2+}$ and reduced nuclear and DNA fragmentation. In conclusion, GDC induces apoptosis in hepatocytes by a mechanism promoted by increases of $\mathbf{M g}_{\mathrm{i}}{ }^{2+}$ with stimulation of $\mathrm{Mg}^{2+}$-dependent endonucleases. These data suggest for the first time that changes of $\mathbf{M g}_{i}^{2+}$ may participate in the program of cellular events culminating in apoptosis. (J. Clin. Invest. 1994. 94:2183-2192.) Key words: bile salts - DNA fragmentation • endonucleases • multiparameter digitized video microscopy $\bullet$ zinc
\end{abstract}

\section{Introduction}

Hepatocellular retention of bile salts contributes to cholestatic liver disease $(1,2)$. Indeed, improvement of human cholestatic liver diseases by the administration of the hydrophilic bile salt ursodeoxycholate, which displaces hydrophobic bile salts from the hepatocyte, highlights the importance of bile salt-induced liver injury (3). Understanding the cellular mechanisms of bile

Preliminary portions of this work were presented at the 44th meeting of the American Association for the Study of Liver Diseases and at the 95th meeting of the American Gastroenterological Association and were published in abstract form (1993. Hepatology. 18:133a) (1994. Gastroenterology. 106:958a).

Address correspondence to Gregory J. Gores, M.D., Associate Professor of Medicine, Center for Basic Research in Digestive Diseases, Mayo Clinic and Mayo Foundation, Rochester, MN 55905.

Received for publication 26 April 1994 and in revised form 2 August 1994.

The Journal of Clinical Investigation, Inc.

Volume 94, December 1994, 2183-2192 salt-mediated hepatocyte injury may provide further therapeutic strategies for the treatment of human cholestatic liver diseases (4). However, the precise cellular mechanisms by which bile acids produce liver injury are unknown and remain controversial. Due to the detergent-like effect of the bile salt steroidal moiety, hepatocellular injury has been postulated to result from direct membrane damage, and the degree of hepatocellular damage has been postulated to be related to bile salt hydrophobicity (5). Nondetergent mechanisms of bile salt toxicity have also been proposed such as injury due to increases in cytosolic free calcium $\left(\mathrm{Ca}_{\mathrm{i}}^{2+}\right)^{1}(6,7)$. All of these models of bile salt-induced hepatocyte injury are associated with lysis of the plasma membrane and cell necrosis. However, widespread hepatocyte necrosis is not a prominent feature of cholestatic liver disease. In contrast, cell dropout associated with acidophilic bodies is frequently identified in human cholestatic liver disease (8). These histopathologic findings are now recognized as morphologic features of cell death by a process referred to as apoptosis (8).

Apoptosis is a form of cell death during which the cell actively participates in its own death by the activation of a specific program of events. Apoptosis is defined by distinctive early and late morphologic features. Early morphologic features include cell volume loss, condensation of nuclear chromatin against the nuclear membrane, and the development of organelle-containing blebs. Nuclear fragmentation also occurs early in apoptosis. Later, the cell fragments into membrane-bound fragments. These cell fragments, traditionally referred to as acidophilic bodies in the liver, are now termed apoptotic bodies (8). The biochemical mechanisms of apoptosis leading to these morphologic changes remain unclear. Changes in DNA integrity are the most characteristic biochemical feature of apoptosis. DNA is thought to be initially cleaved into 300 - and/or $50-\mathrm{kb}$ fragments and then efficiently and thoroughly degraded into nucleosomal-sized fragments (9). Indeed, the appearance of a ladder of nucleosomal-sized DNA fragments on agarose gel electrophoresis has become an identifying feature of apoptosis (10). This characteristic pattern of DNA cleavage occurs by endogenous, nuclear endonucleases. Indeed, activation of endonucleases has been proposed as a molecular mechanism causing apoptosis (11). The precise program of events leading to enhanced endonuclease activity remains unclear, varies between cell type, and may depend on the stimulus inducing apoptosis (11). Postulated mechanisms leading to enhanced endonuclease activity include increases in $\mathrm{Ca}_{\mathrm{i}}^{2+}$ and de novo macromolecular synthesis of endonucleases or endonuclease-activating factors (11).

1. Abbreviations used in this paper: $\mathrm{AO}$, acridine orange; $\mathrm{Ca}_{\mathrm{i}}^{2+}$, cytosolic free calcium; DC, deoxycholate; GDC, glycodeoxycholate; $\mathrm{Mg}_{\mathrm{i}}^{2+}$, cytosolic free magnesium; $\mathrm{pH}_{\mathrm{i}}$, cytosolic $\mathrm{pH}$; TDC, taurodeoxycholate. 
In addition to its physiological role in normal cell turnover as well as regression of liver hyperplasia $(8,12)$, apoptosis contributes to hepatocyte cytotoxicity by toxins. Various hepatotoxins such as 1,1 ,dichloroethylene, dimethylnitrosamine, and cis-platinum have all been shown to cause liver injury by apoptosis (13-15). These numerous observations demonstrating toxin-induced hepatocyte apoptosis suggested toxic bile salts may be responsible for the occurrence of apoptosis in cholestasis. To determine if toxic bile salts can cause apoptosis, we chose to study deoxycholate and its conjugates based on the following rationale. First, deoxycholates are hydrophobic bile salts which are toxic to hepatocytes $(3,16)$. Second, deoxycholates comprise $\sim 25 \%$ of the bile salts in human hepatic ductular bile, and serum concentrations of deoxycholate increase in cholestasis $(17,18)$. Third, deoxycholates can damage DNA of mammalian cells in vivo (19). Finally, high concentrations of dihydroxy bile salts increase cytosolic free concentrations of $\mathrm{Ca}^{2+}(20)$, a physiologic event which mediates apoptosis in other cell types $(11,21)$. In addition to increasing $\mathrm{Ca}_{\mathrm{i}}^{2+}$ by releasing $\mathrm{Ca}^{2+}$ from intracellular stores, deoxycholates also activate nonselective plasma membrane cation conductance channels permitting entry of cations into the cell (22). Entry of $\mathrm{Ca}^{2+}$ and/or $\mathrm{Mg}^{2+}$ through these channels could also potentially activate $\mathrm{Ca}^{2+} / \mathrm{Mg}^{2+}$-dependent endonucleases (11). Therefore, the overall objective of the present study was to determine if deoxycholates induce apoptosis in hepatocytes. Our specific aims were to answer the following questions during cytotoxicity by deoxycholates. Are the distinctive morphologic features of apoptosis present? Do the biochemical features of apoptosis occur? If the morphologic and biochemical features of apoptosis occur, do they require macromolecular synthesis? Are changes in divalent cation concentrations responsible for mediating the morphological and biochemical features of apoptosis?

\section{Methods}

Hepatocyte isolation and culture. The use and care of the animals for these studies was reviewed and approved by the Institutional Animal Care and Use Committee at the Mayo Clinic. Hepatocytes were isolated from fed adult male Sprague-Dawley rats $(250-350 \mathrm{~g})$ as previously described by us in detail (23). For culturing, the hepatocytes were resuspended in culture medium at $0.5 \times 10^{6} \mathrm{cells} / \mathrm{ml}$. 1-ml aliquots were cultured in $35 \times 10$-mm Petri dishes (Becton Dickinson Labware, Lincoln Park, NJ) on 22-mm-square glass coverslips coated with type 1 collagen from rat tail tendon (24). The culture medium used was Waymouth's MB-752/1 containing $100 \mathrm{nM}$ insulin. For those experiments using magnesium-free or sodium-free medium, the medium used was identical except that either no magnesium was added or sodium chloride was replaced by an equimolar amount of choline chloride. Unless otherwise indicated, hepatocytes were used after 3-4 h of culture in $5 \% \mathrm{CO}_{2} /$ air at $37^{\circ} \mathrm{C}$. Freshly isolated and cultured rat hepatocytes were used in our study to avoid the effect of dedifferentiation and subsequent decrease in intrahepatic bile salt uptake that occurs with longer term cultures $(25,26)$.

Solutions. Krebs-Ringers-Hepes buffer contained (mM): $115 \mathrm{NaCl}$, $1 \mathrm{KH}_{2} \mathrm{PO}_{4}, 2 \mathrm{CaCl}_{2}, 5 \mathrm{KCl}, 1.2 \mathrm{MgSO}_{4}$, and $25 \mathrm{Na}$-Hepes buffer, $\mathrm{pH}$ 7.4 (27). Nucleic acid isolation buffer contained $5 \mathrm{mM}$ Tris, $20 \mathrm{mM}$ EDTA, and $0.5 \%$ Triton X-100 (vol/vol) (pH 8.0). Tris-EDTA (TE) buffer contained $10 \mathrm{mM}$ Tris, $1 \mathrm{mM}$ EDTA, $\mathrm{pH}$ 8.0. Endonuclease extraction buffer contained $(\mathrm{mM}): 300 \mathrm{NaCl}, 1$ EDTA, 20 Tris, pH 7.4. Fura-2-AM and Mag-Fura-2-AM were stored in dimethylsulfoxide as $1 \mathrm{mM}$ solutions at $-20^{\circ} \mathrm{C}$.

Assessment of nuclear fragmentation (apoptosis) and cell necrosis. We used a slight modification of the technique of Oberhammer et al.
(28) to quantitate nuclear changes indicative of apoptosis. Instead of using Hoechst 33258, we used acridine orange (AO) as a membrane permeant fluorescent DNA binding dye $(15,29,30)$. Concomitant with AO, we also used propidium iodide to positively identify necrotic cells (30). Cultured hepatocytes were stained with $5 \mu \mathrm{M} \mathrm{AO}$ and $1 \mu \mathrm{M}$ propidium iodide; the coverslips were transferred to a glass slide and viewed under a photomicroscope at a magnification of 250 (Carl Zeiss, Inc., Thornwood, NY). AO fluorescence was visualized using 450-490$\mathrm{nm}$ excitation and 515-565-nm emission filters, respectively. Propidium iodide fluorescence was visualized using excitation and emission filters of 546 and $590 \mathrm{~nm}$, respectively. Fluorescent-stained nuclei were considered to be fragmented if at least three separate fragments of condensed chromatin were identified in a cell (28). At least 300 cells in four highpower fields were counted, and nuclear fragmentation was expressed as a percentage of total cells excluding propidium iodide. Cell necrosis represents cells staining with propidium iodide expressed as a percentage of total cells.

Monitoring of cell blebbing. Cultured hepatocytes were monitored over time for cell blebbing using an inverted microscope (Axiovert; Carl Zeiss, Inc.). Blebbing was scored using phase-contrast optics at a magnification of 400 as described previously by us (31).

Electron microscopy. Cells were fixed in $1 \%$ glutaraldehyde and

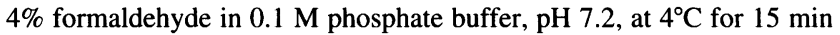
(32). For transmission electron microscopy, the cells were then rinsed for $30 \mathrm{~min}$ in three changes of $0.1 \mathrm{M}$ phosphate buffer, $\mathrm{pH} \mathrm{7.2,} \mathrm{followed}$ by a $1-\mathrm{h}$ postfix in phosphate-buffered $1 \% \mathrm{OsO}_{4}$. After rinsing in three changes of distilled water for $30 \mathrm{~min}$, the cells were stained with $2 \%$ uranyl acetate for $30 \mathrm{~min}$ at $60^{\circ} \mathrm{C}$. Next, the cells were rinsed in three changes of distilled water, dehydrated in progressive concentrations of ethanol followed by $100 \%$ propylene oxide, and embedded in Spurr's resin (33). Sections $(90 \mathrm{~nm}$ ) were cut on an LKB Ultratome III (Mager Scientific, Dexter, MI), placed on 200-nm mesh copper grids, and stained with lead citrate. Micrographs were taken (model 1200; JEOL U. S. A. Inc., Peabody, MA) at $60 \mathrm{kV}$. For scanning electron microscopy, cells were fixed and rinsed with phosphate buffer as above. The cells were dehydrated in progressive concentrations of ethanol (60$100 \%$ ), loaded into Critical Point Dryer holder, immediately reimmersed into $100 \%$ ethanol, and run in the Critical Point Dryer (Polaron Instruments Inc., Hatfield, PA). The cells were coated with $\mathrm{Au} / \mathrm{Pd}$, and micrographs were taken (model 2400 SEM; JEOL U. S. A. Inc.).

Measurement of DNA fragmentation. DNA fragmentation was assessed using the method of Wyllie et al. (34). Briefly, control or treated cells were gently scraped from the dishes and centrifuged ( $150 \mathrm{~g}$ for 2 $\min$ ) to collect the cells. The supernatant was aspirated, and the cell pellet was resuspended in $1 \mathrm{ml}$ of ice-cold nucleic acid isolation buffer and incubated for $20 \mathrm{~min}$ on ice. Next, the samples were centrifuged for $20 \mathrm{~min}$ at $27,000 \mathrm{~g}$ to separate high molecular weight chromatin in the pellet from cleavage products (DNA fragments) in the supernatant. Pellets were resuspended in $1 \mathrm{ml}$ of TE buffer. DNA was quantitatively measured in the pellets and supernatants using the diphenylamine reagent (35). The unsedimented DNA $(27,000 \mathrm{~g})$ in the supernatant was expressed as a percentage of the total DNA in the supernatant plus the pellet.

Isolation of DNA and gel electrophoresis. Hepatocytes $\left(10^{6}\right.$ cells/ $\mathrm{ml}$ ) were cultured in Waymouth's MB 752/1 medium on $100 \times 15$ $\mathrm{mm}$ plastic culture dishes ( $10 \mathrm{ml} / \mathrm{dish}$ ). At the desired time, the medium was aspirated, and $2 \mathrm{ml}$ of a commercially available lysis buffer (Applied Biosystems, Foster City, CA) containing urea, lauroyl sarcosine, CDTA, $\mathrm{NaCl}$, and Tris/ $\mathrm{HCl}, \mathrm{pH} 7.9$, with $200 \mu \mathrm{g}$ proteinase $\mathrm{K} / \mathrm{ml}$, was added to each dish. The contents of the dishes were transferred into 15$\mathrm{ml}$ conical centrifuge tubes $(4 \mathrm{ml} /$ tube $)$ and incubated for $1 \mathrm{~h}$ at $55^{\circ} \mathrm{C}$. The solution was extracted twice with $8 \mathrm{ml}$ of $1: 1 \mathrm{phenol} /$ chloroform. DNA was precipitated from the aqueous layer with $5 \mathrm{ml}$ of ice-cold $95 \%$ ethanol and collected by centrifugation at $1,000 \mathrm{~g}$ for $10 \mathrm{~min}$ at $4^{\circ} \mathrm{C}$. The DNA was resuspended in $2 \mathrm{ml}$ of TE buffer, and the tube was gently agitated on a rotating platform (multipurpose rotator, motor 151; Scientific Industries, Bohemia, NY) for $2 \mathrm{~h}$ at $4^{\circ} \mathrm{C}$ to dissolve the DNA. The DNA-containing solution was incubated with RNase $(20 \mu \mathrm{g} / \mathrm{ml})$ 
for $45 \mathrm{~min}$ at $37^{\circ} \mathrm{C}$. Next, the DNA solution was reextracted once with $4 \mathrm{ml}$ of $1: 1$ phenol/chloroform, precipitated with $95 \%$ ethanol, and centrifuged as described above. The DNA pellet was resuspended in $500 \mu \mathrm{l}$ TE buffer and allowed to dissolve gently on a rotating platform at $4^{\circ} \mathrm{C}$ overnight. DNA yield was quantitated by measuring the $\mathrm{OD}_{2(0)}$ of an aliquot of each sample dissolved in distilled water. Gel electrophoresis of the DNA ( $4 \mu \mathrm{g} /$ well) was performed at $6 \mathrm{~V} / \mathrm{cm}$ for $2 \mathrm{~h}$ on a $2 \%$ agarose gel using a buffer containing $1 \mu \mathrm{M}$ ethidium bromide and $0.04 \mathrm{M}$ Tris acetate, $1 \mathrm{mM}$ EDTA $(\mathrm{pH} \mathrm{7.4)}$, and a loading buffer containing $0.25 \%$ xylene cyanole FF, $0.25 \%$ bromophenol blue, $40 \%$ sucrose, and $1 \mu \mathrm{M}$ ethidium bromide (36). The gel was visualized by ultraviolet light fluorescence and photographed using Polaroid film and a photo-documentation camera (FB PDC-34; Fisher Scientific Co., Pittsburgh, PA).

Measurement of cytosolic free calcium $\left(\mathrm{Ca}_{i}^{2+}\right)$, magnesium $\left(\mathrm{Mg}_{i}^{2+}\right)$, and $\mathrm{pH}\left(\mathrm{pH}_{i}\right)$. In single cultured rat hepatocytes, digitized video microscopy was used to quantitate $\mathrm{Ca}_{i}^{2+}, \mathrm{Mg}_{i}^{2+}$, and $\mathrm{pH}_{\mathrm{i}}(23)$. Experiments measuring $\mathrm{Ca}_{i}^{2+}$ and $\mathrm{pH}_{\mathrm{i}}$ were performed using Fura-2 and $\left(2^{\prime}, 7^{\prime}\right)$-bis (carboxyethyl) - (5,6)-carboxyfluoresein-loaded hepatocytes, respectively, as we have described previously in detail (23, 24). For measurements of $\mathrm{Mg}_{\mathrm{i}}^{2+}$, Mag-Fura-2 was loaded into cultured hepatocytes in culture medium using $5 \mu \mathrm{M}$ Mag-Fura-2-acetoxymethylester for $30 \mathrm{~min}$ at $37^{\circ} \mathrm{C}(37) . \mathrm{Mg}_{\mathrm{i}}^{2+}$ was quantitated by ratio imaging of Mag-Fura-2 fluorescence excited at $340 \mathrm{~nm}$ and $380 \mathrm{~nm}$ (37). Fluorescence was imaged through a 395-nm dichroic reflector and 470-550$\mathrm{nm}$ emission filter. The mean values for pixel ratios for individual cells were converted to $\mathrm{Mg}^{2+}$ using the calculation described by Grynkiewicz et al. (38) and a dissociation constant of $1.5 \mathrm{mM}$ for the Mag-Fura-2$\mathrm{Mg}^{2+}$ complex (37). The values for $R_{\min }, R_{\max }$, and the constant $\mathrm{Sf}_{2} /$ $\mathrm{Sb}_{2}$ were calculated from measurements with Mag-Fura-2 free acid solutions in capillary tubes (internal diameter $20 \mathrm{~mm}$; Vitro Dynamics Inc., Rockaway, $\mathrm{NJ}$ ) placed on the microscope stage.

Preparation of soluble nuclear protein extracts with endonuclease activity. Soluble nuclear protein extracts, which contain nuclear endonuclease activity, were obtained using the technique described by Schwartzman et al. (39). Freshly isolated hepatocytes were centrifuged at $400 \mathrm{~g}$ for $3 \mathrm{~min}$, the supernatant was discarded, and the pellet was resuspended in cold $0.25 \%$ Nonidet P-40 for 5 min to obtain intact, isolated nuclei. The nuclei were collected by centrifugation at $400 \mathrm{~g}$ for $3 \mathrm{~min}$ and resuspended in a high-salt endonuclease extraction buffer. The mixture was then rotated for $1 \mathrm{~h}$ at $4^{\circ} \mathrm{C}$. Soluble nuclear protein extract was obtained after pelleting the chromatin by centrifugation at $165,000 \mathrm{~g}$ for $1 \mathrm{~h}$ at $4^{\circ} \mathrm{C}$. The protein concentration of the resulting supernatant was determined using the fluorescamine assay (40).

Endonuclease assay. Endonuclease activity was determined in hepatocyte nuclear protein extracts using ethidium bromide/salmon testis DNA as a substrate as described by Yonemura and Maeda (41). The intercalation of ethidium bromide into double-stranded DNA results in a marked increase in ethidium bromide fluorescence; endonuclease activity with cleavage and fragmentation of DNA results in loss of ethidium bromide intercalation sites causing a decrease in ethidium bromide fluorescence. $400 \mu \mathrm{g}$ of nuclear extract protein in $100 \mu \mathrm{l}$ of $50 \mathrm{mM}$ Tris buffer ( $\mathrm{pH} 7.4$ ) was added to $100 \mu \mathrm{l}$ of $10 \mu \mathrm{M}$ ethidium bromide and $1.8 \mathrm{ml}$ of salmon testis DNA solution $(75 \mu \mathrm{g} / \mathrm{ml})$. Fluorescence was quantitated in a luminescence spectrometer/fluorometer (model LS50; Perkin-Elmer Corp., Norwalk, CT), using excitation and emission wavelengths of 546 and $590 \mathrm{~nm}$, respectively. The fluorometer was equipped with a magnetic stirrer and warmed with recirculating water at $37^{\circ} \mathrm{C}$ using a recirculating water pump. Endonuclease activity was expressed as equivalent units of a commercially available Serratia marcescens endonuclease.

Measurement of ATP. ATP was quantitated using the luciferin/ luciferase assay, as previously described in detail, in $1-\mathrm{ml}$ aliquots of hepatocytes suspended in culture medium $\left(10^{6} \mathrm{ml}\right)$ at $37^{\circ} \mathrm{C}(31)$.

Statistical analysis. All data represent at least three experiments using cells from a minimum of three separate isolations and are expressed as mean \pm standard error of the mean unless otherwise indicated. Differences between groups were analyzed using an analysis of variance

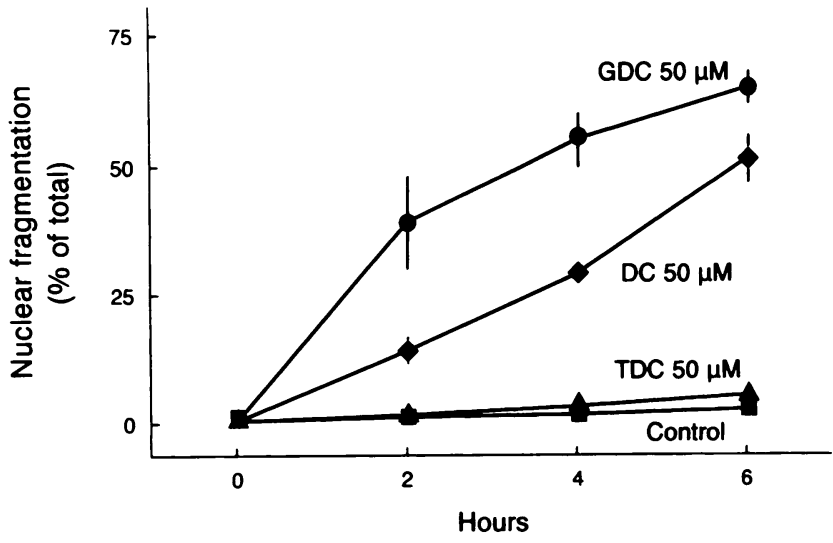

Figure 1. DC and its conjugates cause nuclear fragmentation in rat hepatocytes. Cultured rat hepatocytes were incubated in culture media at $37^{\circ} \mathrm{C}$ in the absence of bile salt (control, closed squares) or with 50 $\mu \mathrm{M}$ GDC (closed circles), TDC (closed triangles), or DC (closed diamonds). At each time point, cells were stained with $5 \mu \mathrm{M} \mathrm{AO}$ and $1 \mu \mathrm{M}$ propidium iodide; the coverslips were then gently transferred to a glass slide and viewed with a fluorescence microscope. At least 300 cells in 4 high-power fields were counted; nuclear fragmentation represents cells with at least three nuclear fragments expressed as a percentage of total cells counted.

for repeated measures and a post-hoc Bonferroni test to compare for multiple comparisons. All statistical analyses were performed with the statistical software package InStat (GraphPAD, San Diego, CA).

Materials. All chemicals used were of analytical grade purity. The bile acids used were $>96 \%$ pure by thin-layer chromatography performed by the manufacturers and were used without further purification. ATP assay mix, glycodeoxycholate (GDC), taurodeoxycholate (TDC), deoxycholate (DC), zinc sulfate, propidium iodide, DNase, xylene cyanole, bromophenol blue, paraldehyde, Tris/HCl, EDTA, Triton X-100, RNase, AO, diphenylamine, ethidium bromide, and recombinant $S$. marcescens endonuclease were from Sigma Chemical Co. (St. Louis, $\mathrm{MO}$ ); proteinase $\mathrm{K}$ and collagenase type $\mathrm{D}$ were obtained from Boehringer Mannheim Biochemicals (Indianapolis, IN); Fura-2, Mag-Fura$2,\left(2^{\prime}, 7^{\prime}\right)$-bis ( carboxyethyl) - (5.6)-carboxyfluorescein, Fura-2-acetoxymethylester (Fura 2-AM), and Mag-Fura-2-acetoxymethylester (MagFura 2-AM) were obtained from Molecular Probes, Inc. (Eugene, OR); acetic acid was obtained from Fisher Scientific Co.; and Hepes buffer was obtained from United States Biochemical Corp. (Cleveland, $\mathrm{OH}$ ).

\section{Results}

\section{Morphologic features of apoptosis}

Is nuclear fragmentation induced by DC and its conjugates? Nuclear fragmentation was quantitated in AO-stained cells after incubation of hepatocytes with DC and its conjugates, GDC and TDC. After $4 \mathrm{~h}$ of incubation, nuclear fragmentation occurred in $55 \pm 5 \%$ of cells incubated with $50 \mu \mathrm{M}$ GDC, $28 \pm 2 \%$ of cells incubated with $50 \mu \mathrm{M} \mathrm{DC}$, but only $2 \pm 1 \%$ of those cells incubated with $50 \mu \mathrm{M}$ TDC (Fig. 1). Nuclear fragmentation with GDC was dose dependent between concentrations of 0 and 100 $\mu \mathrm{M}(r=0.93$ at $4 \mathrm{~h}$ ) (Fig. 2 ). After $4 \mathrm{~h}$ of incubation, $>85 \%$ of cells treated with $50 \mu \mathrm{M}$ DC, TDC, and GDC excluded propidium iodide, indicating the absence of cell lysis or necrosis (Table I). In contrast, after incubation of cells for $4 \mathrm{~h}$ with concentrations of GDC $>100 \mu \mathrm{M}$, cells no longer excluded propidium iodide, indicating cell lysis (necrosis). Because nearmaximal nuclear fragmentation in the absence of significant 


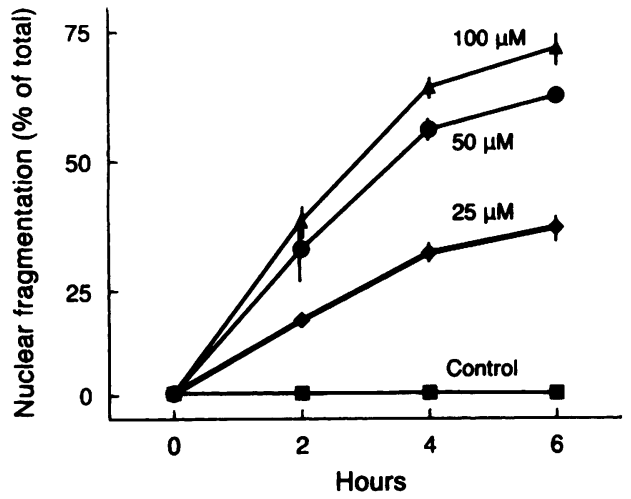

Figure 2. Time course and concentration dependence of GDC-induced nuclear fragmentation. Cultured rat hepatocytes were incubated with various concentrations of GDC $(0-100 \mu \mathrm{M})$. At each time point, cells were stained with $5 \mu \mathrm{M} \mathrm{AO}$ and $1 \mu \mathrm{M}$ propidium iodide; the coverslips were then gently transferred to a glass slide and viewed with a fluorescence microscope. At least 300 cells in 4 high-power fields were counted; nuclear fragmentation represents cells with at least three nuclear fragments expressed as a percentage of total cells counted.

cell necrosis was observed with $50 \mu \mathrm{M}$ GDC, we used this concentration and conjugate of deoxycholate for the remainder of our studies.

To exclude a direct physicochemical effect of extracellular GDC on the permeability of the plasma membrane as a cause of the nuclear changes. GDC-induced nuclear fragmentation was assessed in the presence of $3 \%$ albumin. At this concentration $>90 \%$ of bile salts are protein bound (42). Nuclear fragmentation was similar in the presence and absence of albumin ( $43 \pm 5$ vs. $54 \pm 3 \%$ at $4 \mathrm{~h} ; P=\mathrm{NS}$ ). When sodium in the incubation medium was replaced isotonically with choline, GDC-induced nuclear fragmentation was reduced over twofold ( $22 \pm 7$ vs. $52 \pm 4 \%$ at $4 \mathrm{~h} ; P<0.01$ ), suggesting that sodiumdependent bile salt uptake into the cell promoted the morphologic nuclear changes. Thus, the observed nuclear changes likely occur after intracellular accumulation of bile salts.

Are the distinctive ultrastructural features of apoptosis observed with GDC? Scanning electron microscopy of hepatocytes treated for $3 \mathrm{~h}$ with $50 \mu \mathrm{M}$ GDC revealed early surface morphological features suggestive of apoptosis (Fig. 3, $B$ and $D$ ) while no morphologic changes were observed in controls (Fig. 3, A and $C$ ). The morphologic hallmarks of apoptosis in GDCtreated cells included loss of microvilli and prominent bleb formation (Fig. 3, $B$ and $D$ ). Transmission electron microscopy of GDC-treated cells demonstrated chromatin condensation, nuclear fragmentation, and blebs containing intact organelles (Fig. $4 \mathrm{~B}$ ). Occasional cells were at a more advanced stage with complete fragmentation into membrane-bound cytoplasmic fragments containing intact organelles or apoptotic bodies (Fig. 5), a morphological finding demonstrating unequivocally the occurrence of apoptosis in GDC-treated hepatocytes.

\section{Biochemical features of apoptosis}

Does DNA fragmentation occur during GDC cytotoxicity? We assessed DNA fragmentation by two independent, complementary approaches: demonstration of DNA fragmentation by gel electrophoresis and by DNA sedimentation characteristics. The typical nucleosomal ladder of DNA fragments on agarose gel electrophoresis was observed after incubation of hepatocytes
Table I. Bile Salt-induced Nuclear and DNA Fragmentation*

\begin{tabular}{lccc}
\hline \multicolumn{1}{c}{ Treatment } & $\begin{array}{c}\text { DNA } \\
\text { fragmentation }\end{array}$ & $\begin{array}{c}\text { Nuclear } \\
\text { fragmentation }\end{array}$ & $\begin{array}{c}\text { Propidium iodide } \\
\text { staining }\end{array}$ \\
\hline & $\%$ & $\%$ & $\%$ \\
Untreated & $5 \pm 1$ & $1 \pm 1$ & $5 \pm 1$ \\
TDC 50 $\mu \mathrm{M}$ & $6 \pm 2$ & $2 \pm 1$ & $6 \pm 1$ \\
DC $50 \mu \mathrm{M}$ & $24 \pm 4$ & $28 \pm 5$ & $11 \pm 4$ \\
GDC $50 \mu \mathrm{M}$ & $59 \pm 12$ & $55 \pm 2$ & $12 \pm 2$ \\
GDC 50 $\mu \mathrm{M}$ plus & & & \\
cycloheximide 100 $\mu \mathrm{M}$ & $46 \pm 10$ & $27 \pm 7$ & $23 \pm 3$ \\
actinomycin D 5 $\mu \mathrm{g} / \mathrm{ml}$ & $55 \pm 11$ & $58 \pm 12$ & $18 \pm 3$ \\
zinc sulfate 500 $\mu \mathrm{M}$ & $9 \pm 2$ & $4 \pm 2$ & $9 \pm 2$ \\
$\mathrm{Mg}^{2+}$-free medium & $27 \pm 5$ & $28 \pm 5$ & $14 \pm 4$ \\
& & & \\
\hline
\end{tabular}

* Hepatocytes were incubated for $4 \mathrm{~h}$ with the indicated agents before determination of nuclear fragmentation, propidium iodide exclusion, and DNA fragmentation as described in Methods. Nuclear fragmentation represents cells with at least three nuclear fragments expressed as a percentage of the total cells counted. Propidium iodide staining represents the number of cells staining with propidium iodide as a percentage of total cells counted. DNA fragmentation is expressed as the percentage of total DNA that resisted sedimentation at $27,000 \mathrm{~g}$.

with $50 \mu \mathrm{M}$ GDC for $4 \mathrm{~h}$ (Fig. 6). In contrast, when hepatocytes were incubated with GDC plus the endonuclease inhibitor zinc sulfate (500 $\mu \mathrm{M})$, no DNA cleavage was observed (Fig. 6) (11). Similar results were obtained when DNA fragmentation was assessed by quantitating the sedimentation characteristics of DNA (Table I). These results demonstrate internucleosomal DNA cleavage in GDC-treated cells.

Is macromolecular synthesis required for GDC-induced apoptosis? To determine if ongoing macromolecular synthesis was required for GDC-induced apoptosis we assessed the effect of cycloheximide $(100 \mu \mathrm{M})$, an inhibitor of translation, and actinomycin D $(5 \mu \mathrm{g} / \mathrm{ml})$, an inhibitor of transcription, on nuclear and DNA fragmentation induced by GDC (Table I). These agents did not prevent GDC-induced nuclear or DNA fragmentation. However, the endonuclease inhibitor zinc sulfate (500 $\mu \mathrm{M}$ ) prevented nuclear fragmentation in cells treated with GDC (Table I). Thus, endonuclease activity appears to mediate GDCinduced apoptosis by a mechanism independent of macromolecular synthesis.

What is the cation dependence of hepatocyte nuclear endonucleases? The in vitro calcium and magnesium dependence of hepatocyte, nuclear endonuclease activity was quantitated in nuclear protein extracts (Table II). No activity was observed in the presence of $0.5 \mathrm{mM}$ EDTA. Endonuclease activity was observed with either $\mathrm{Ca}^{2+}$ or $\mathrm{Mg}^{2+}$, but was 2.5 -fold greater in the presence of $\mathrm{Mg}^{2+}(0.5 \mathrm{mM})$ compared with $\mathrm{Ca}^{2+}(2 \mathrm{mM})$. Endonuclease activity increased linearly with concentrations of $\mathrm{Mg}^{2+}$ between 0 and $1.0 \mathrm{mM}(r=0.98)$ and was 1.57 -fold greater at $0.9 \mathrm{mM}$ compared with $0.5 \mathrm{mM}$ ( Table II). No difference was observed in endonuclease activity or cation dependence of endonucleases in nuclear protein extracts from hepatocytes treated with GDC compared with controls (Table II). Addition of GDC to the in vitro assay did not alter endonuclease activity, demonstrating that GDC does not directly activate nuclear endonucleases. $\mathrm{Zn}^{2+}$ completely inhibited endonuclease activity in the presence of either $\mathrm{Mg}^{2+}$ or $\mathrm{Ca}^{2+}$, directly demon- 


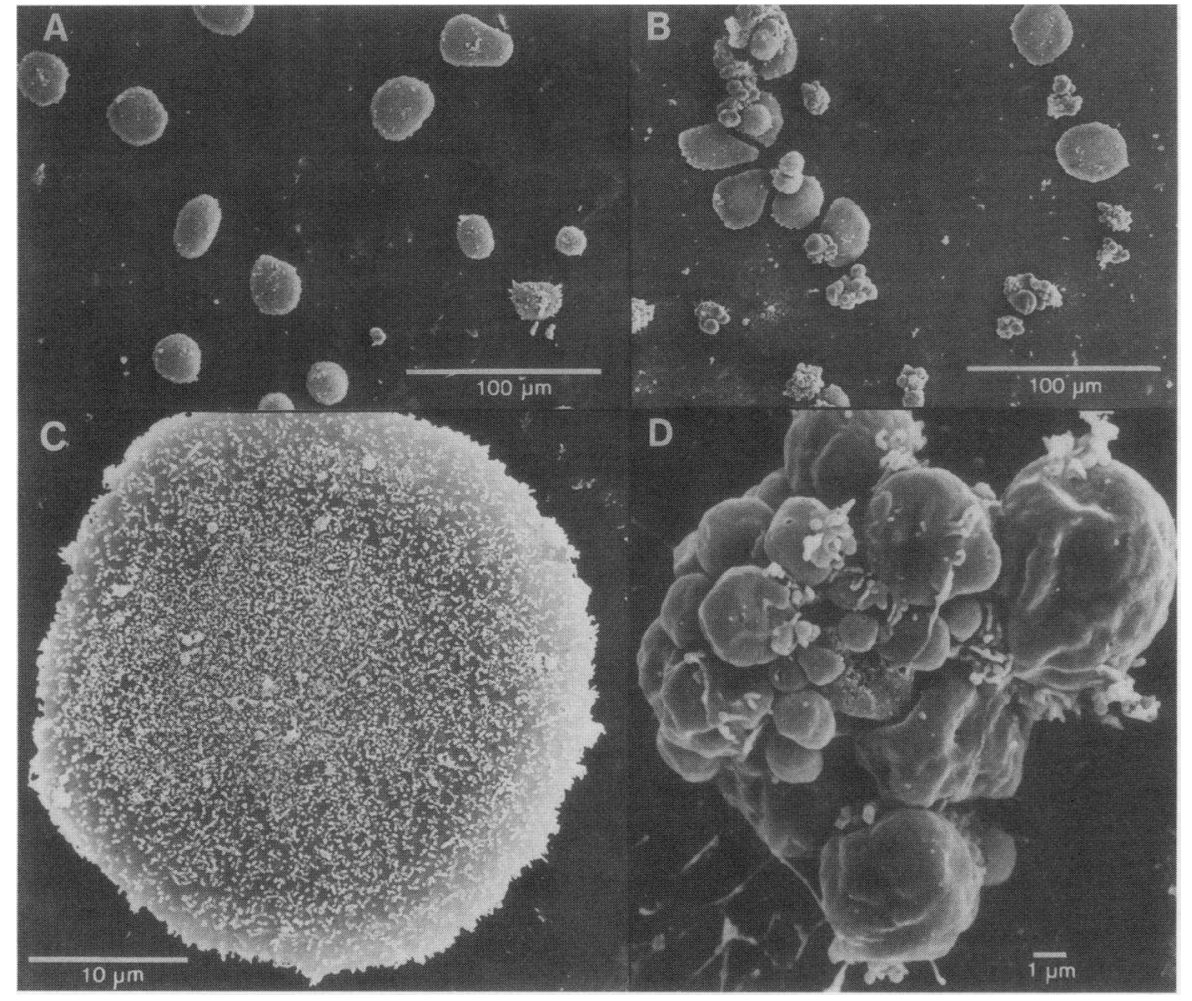

Figure 3. Effect of GDC on hepatocyte surface morphology. Scanning electron microscopy of cultured rat hepatocytes after $3 \mathrm{~h}$ of incubation. ( $A$ ) Hepatocytes incubated without bile salts (control) $(\times 250)$. (B) Hepatocytes incubated with GDC $(50 \mu \mathrm{M})(\times 250)$. (C) Hepatocyte (control) showing prominent cell surface microvilli $(\times 2,000)$. $(D)$ Hepatocyte incubated with GDC ( $50 \mu \mathrm{M})$ $(\times 4,000)$. Note the relatively smooth surface with loss of surface microvilli and the presence of numerous surface blebs. strating that $\mathrm{Zn}^{2+}$ is a potent inhibitor of hepatocyte, nuclear endonuclease activity (Table II) (11). Our results extend the findings of others, demonstrating that hepatocyte, nuclear endonucleases are constitutively expressed, by revealing that $\mathrm{Mg}^{2+}$, in the absence of $\mathrm{Ca}^{2+}$, can activate these endonucleases $(43,44)$.

Is GDC cytotoxicity associated with changes in $\mathrm{Ca}_{i}^{2+}, \mathrm{pH}_{i}$, or $\mathrm{Mg}_{i}^{2+}$ ? After the administration of $50 \mu \mathrm{M}$ GDC, no acute change in $\mathrm{Ca}_{i}^{2+}$ was observed; however, a transient rise of $\mathrm{Ca}_{i}^{2+}$ was obtained with the administration of $10 \mathrm{nM}$ vasopressin used as a positive control (Fig. $7 \mathrm{~A}$ ). In addition, no significant change in $\mathrm{Ca}_{\mathrm{i}}^{2+}$ was observed in GDC-treated hepatocytes over a 4-h period (Fig. $7 B$ ), although cells were observed to undergo light microscopic changes suggestive of apoptosis (i.e., cytoplasmic bleb formation). Likewise, no acute or chronic effects of GDC administration on $\mathrm{pH}_{\mathrm{i}}$ were observed (data not shown ).

In contrast to the results with $\mathrm{Ca}_{\mathrm{i}}^{2+}, \mathrm{Mg}_{\mathrm{i}}^{2+}$ increased twofold after $2 \mathrm{~h}$ of incubation with $50 \mu \mathrm{M}$ GDC (Fig. 8). In hepatocytes, about $94 \%$ of the total cytosolic magnesium is bound to ATP or nondiffusible cytosolic binding sites, and net ATP hydrolysis leads to an increase in $\mathrm{Mg}_{\mathrm{i}}^{2+}$ (45). However, significant ATP depletion did not occur in hepatocytes treated with GDC ( $50 \mu \mathrm{M})$; cellular ATP levels after $2 \mathrm{~h}$ were $90 \pm 8 \%$ of

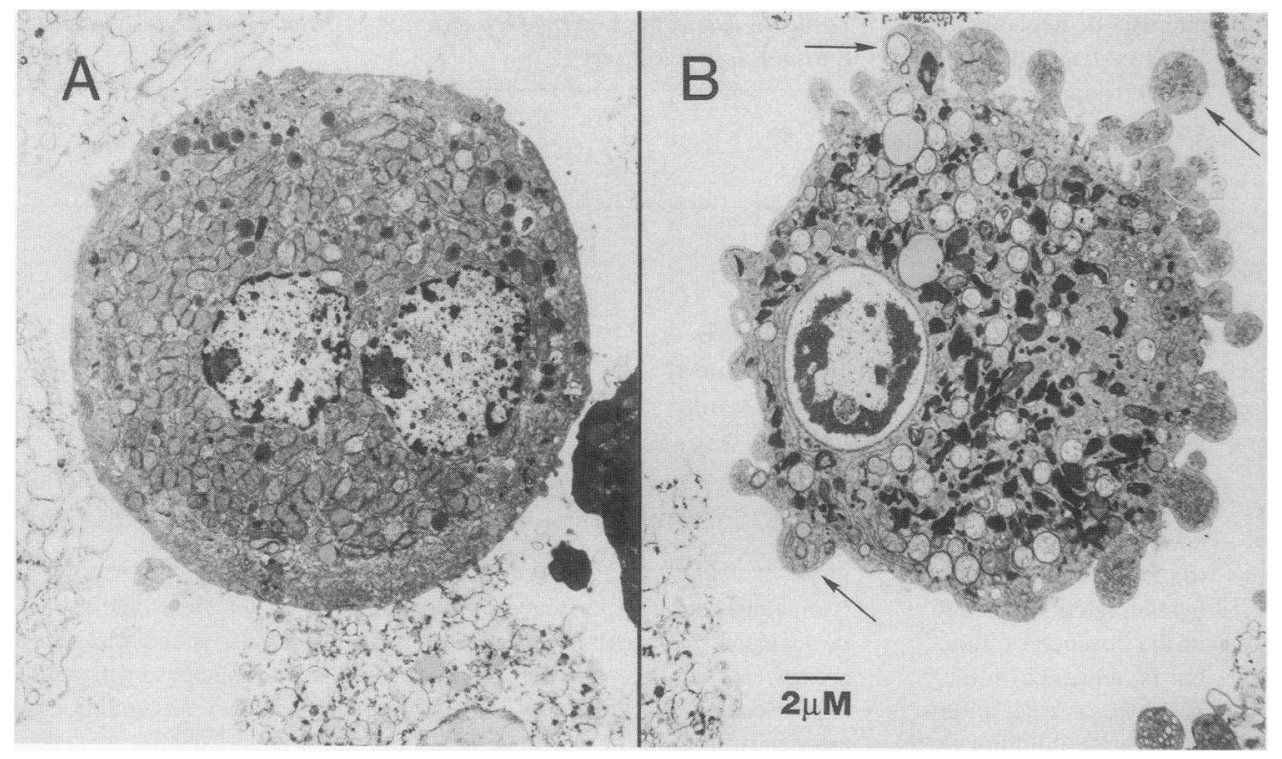

Figure 4. Effect of GDC on hepatocyte ultrastructure. Transmission electron microscopy of cultured rat hepatocytes after $3 \mathrm{~h}$ of incubation. $(A)$ Hepatocyte incubated without bile salt ( control) $(\times 3,000)$. (B) Hepatocyte incubated with GDC (50 $\mu \mathrm{M})$ $(\times 3,000)$. Note the condensation and margination of nuclear chromatin against the nuclear membrane. Surface blebs containing intact organelles are present (arrows). These changes are characteristic of early apoptosis. 


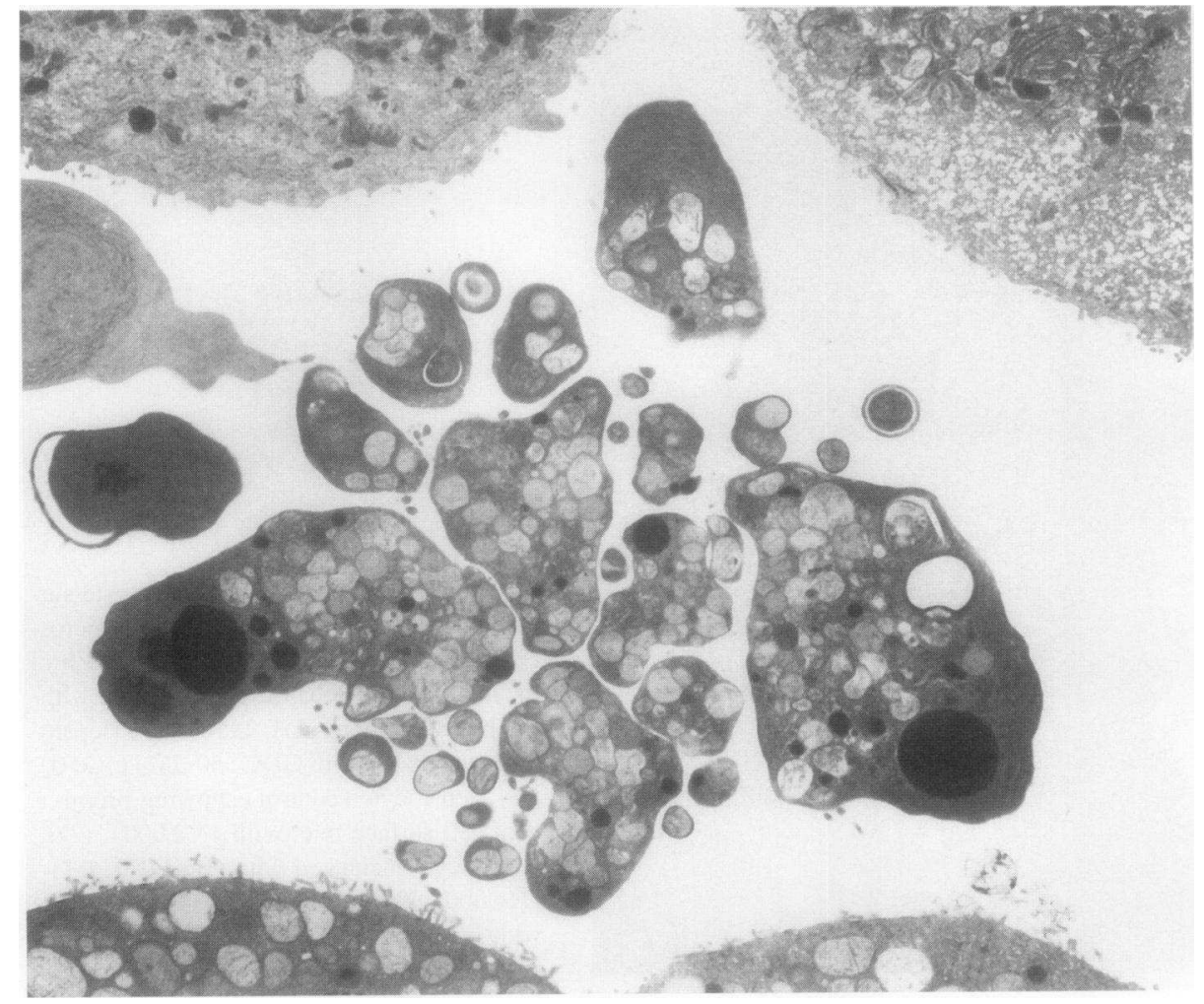

Figure 5. Hepatocyte undergoing GDCinduced apoptosis. Transmission electron microscopy of a hepatocyte incubated for $3 \mathrm{~h}$ with GDC $(50 \mu \mathrm{M})$ showing cellular fragmentation into organelle-containing cytoplasmic (apoptotic) bodies of varying sizes $(\times 3,000)$. untreated cells. The increase of $\mathrm{Mg}_{\mathrm{i}}^{2+}$ was prevented by incubating the cells in an $\mathrm{Mg}^{2+}$-free medium, suggesting the increase of $\mathrm{Mg}_{\mathrm{i}}^{2+}$ was due to an influx of extracellular $\mathrm{Mg}^{2+}$ into the cell (Fig. 8). Incubation of cells in $\mathrm{Mg}^{2+}$-free medium reduced the occurrence of morphological features of GDC-induced apoptosis. Nuclear fragmentation was reduced twofold by omit-

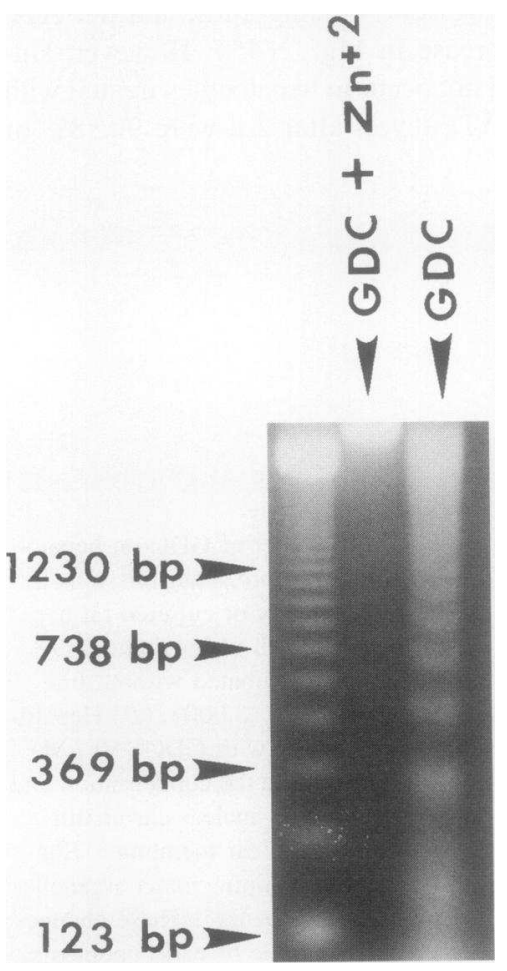

Figure 6. Zinc sulfate inhibits internucleosomal DNA fragmentation induced by GDC. An ethidium bromide-stained agarose gel after electrophoresis of hepatocyte DNA is demonstrated. The left lane contains molecular weight markers. DNA was extracted after incubation of hepatocytes with $50 \mu \mathrm{M} \mathrm{GDC}$ (right lane) or with 50 $\mu \mathrm{M}$ GDC plus $500 \mu \mathrm{M}$ $\mathrm{Zn}^{2+}$ for $4 \mathrm{~h}$. A loss of the large genomic DNA and the concomitant appearance of a ladder-like DNA fragmentation pattern characteristic of apoptosis is present in the DNA from hepatocytes treated with GDC in the absence of zinc, but is abolished in the presence of zinc, an endonuclease inhibitor. ting $\mathrm{Mg}^{2+}$ from the medium (Fig. 9). In addition, during incubation of cells with GDC in $\mathrm{Mg}^{2+}$-free medium, cell blebbing was reduced by $37 \%$ after $4 \mathrm{~h}(43 \pm 5$ vs. $27 \pm 2 \%)$. Incubation of cells in an $\mathrm{Mg}^{2+}$-free medium also reduced the biochemical correlates of GDC-induced apoptosis such as DNA fragmentation (Table I) and internucleosomal cleavage (Fig. 10). The occurrence of necrosis will preclude the changes of apoptosis from occurring; however, the inhibition of apoptosis by omitting $\mathrm{Mg}^{2+}$ from the medium could not be explained by the development of necrosis, as $>85 \%$ of the cells still excluded propidium iodide (Table I). Thus, $\mathrm{Mg}^{2+}$ omission from the medium was

Table II. Divalent Cation Dependence of Rat Hepatocyte Nuclear Endonuclease Activity*

\begin{tabular}{lcc}
\hline \multirow{2}{*}{ Ions } & \multicolumn{2}{c}{ Endonuclease activity } \\
\cline { 2 - 3 } & Controls & GDC-treated \\
\hline & $m U / 30$ min & $m U / 30$ min \\
EDTA & No activity & No activity \\
$\mathrm{Ca}^{2+}(2 \mathrm{mM})$ & $132 \pm 2$ & $132 \pm 11$ \\
$\mathrm{Mg}^{2+}(0.5 \mathrm{mM})$ & $332 \pm 16$ & $343 \pm 14$ \\
$\mathrm{Mg}^{2+}(0.9 \mathrm{mM})$ & $521 \pm 36$ & $547 \pm 35$ \\
$\mathrm{Ca}^{2+}(2 \mathrm{mM})$ plus $\mathrm{Mg}^{2+}(0.5 \mathrm{mM})$ & $229 \pm 12$ & $236 \pm 13$ \\
$\mathrm{Ca}^{2+}(2 \mathrm{mM})$ plus $\mathrm{Zn}^{2+}(0.5 \mathrm{mM})$ & No activity & No activity \\
$\mathrm{Mg}^{2+}(0.5 \mathrm{mM})$ plus $\mathrm{Zn}^{2+}(0.5 \mathrm{mM})$ & No activity & No activity \\
\end{tabular}

* Divalent cation dependence of endonuclease activity was determined in nuclear protein extracts from cultured hepatocytes incubated in the presence or absence of GDC $(50 \mu \mathrm{M})$ for $4 \mathrm{~h}$. Endonuclease activity is expressed as equivalent units of a recombinant $S$. marcescens endonuclease determined in the presence of $2 \mathrm{mM} \mathrm{Ca}^{2+}$. 

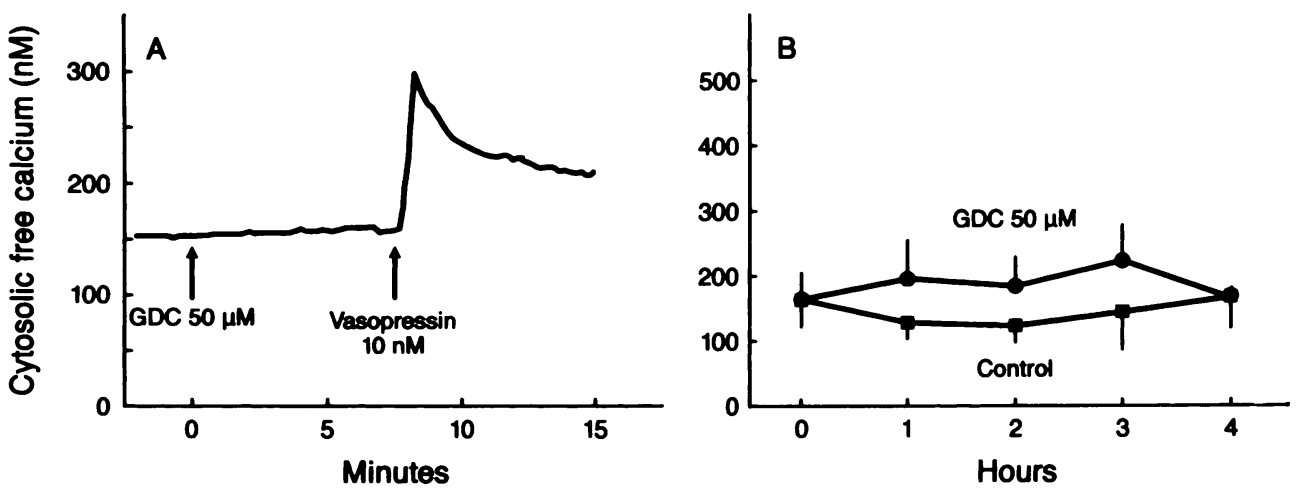

Figure 7. GDC does not alter $\mathrm{Ca}_{i}^{2+} \cdot \mathrm{Ca}_{i}^{2+}$ in single Fura-2loaded cells was monitored by ratio imaging of Fura-2 fluorescence using digitized video microscopy. (A) Acute changes in $\mathrm{Ca}_{i}^{2+}$ after addition of $50 \mu \mathrm{M}$ GDC or $10 \mathrm{nM}$ vasopressin. Results are of one experiment ( $n=6$ cells) representative of four separate experiments. $(B)$ Cells were incubated in the presence (closed circles) and absence (closed squares) of GDC $(50 \mu \mathrm{M}) \cdot \mathrm{Ca}_{i}^{2+}$ was quantitated over $4 \mathrm{~h}$. Each data point represents the mean $\mathrm{Ca}_{i}^{2+}$ of 30 individual cells from each of 4 separate experiments. truly cytoprotective. Although the ladder pattern of oligonucleosomal cleavage was not seen on agarose gel electrophoresis, an apparent decrease in the highest molecular weight band ( $s$ ) was observed which may be indicative of chromatin fragmentation into larger fragments. Furthermore, DNA fragmentation was not completely abolished (Table I). Thus, removal of extracellular magnesium prevented cleavage into oligonucleosomal-sized fragments but may not have prevented DNA cleavage into larger (50- and/or 300-kb) fragments. Our results therefore indicate that both the morphologic changes of apoptosis and internucleosomal cleavage of DNA were promoted by the increase of $\mathrm{Mg}_{\mathrm{i}}^{2+}$.

\section{Discussion}

The major findings of this study relate to the cellular mechanisms of hepatocyte injury by GDC, a toxic, hydrophobic bile salt. In our previous study on bile salt cytotoxicity, we suggested that bile salts caused hepatocyte necrosis due to mitochondrial injury with ATP depletion (23). In this study, we extend our observations by demonstrating for the first time that hepatocyte injury by bile salts can also occur by apoptosis. The mechanisms of bile salt cytotoxicity, necrosis versus apoptosis, appear to be dose dependent. Indeed, concentrations of GDC $>100 \mu \mathrm{M}$ caused cell lysis or necrosis, whereas concentrations of GDC
$<100 \mu \mathrm{M}$ resulted in apoptosis. Necrosis appears to occur when concentrations of bile salts are sufficient to cause mitochondrial injury and ATP depletion, whereas the active process of apoptosis predominates at concentrations insufficient to cause ATP depletion. Although serum concentrations of total bile salt concentrations in cholestasis range from 100 to $300 \mu \mathrm{M}$, the intracellular concentrations remain unknown (46). Furthermore, $\mathrm{Na}^{+}$-dependent bile salt cotransport into the hepatocyte is downregulated in cholestasis as a protective mechanism to limit intracellular bile salt concentrations (47). Thus, the type of liver injury during cholestasis may vary depending upon the concentration of bile salt retained within the hepatocyte. In this regard, our model of GDC-induced hepatocyte injury provides mechanistic insight into the concentration-dependent toxicity of hydrophobic bile salts. Although we used GDC is this study and glycochenodeoxycholate in the previous study, we have also recently demonstrated virtually identical dose-dependent mechanisms of hepatocyte cytotoxicity with glycochenodeoxycholate, apoptosis at concentrations $<100 \mu \mathrm{M}$, and necrosis at concentrations $>100 \mu \mathrm{M}$ (our unpublished observations).

Apoptosis is increasingly recognized as an important mechanism of cell and tissue injury. Early studies emphasized signal transduction events after addition or removal of specific ligands and target cell injury by immunocytes as physiologic mechanisms of apoptosis (48). However, toxic mechanisms of

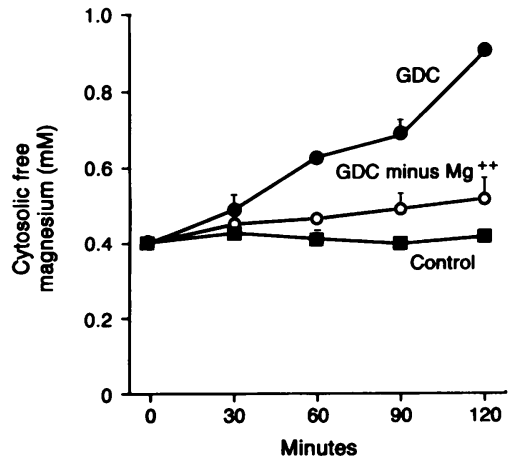
(closed circles) or without (open circles) extracellular $\mathrm{Mg}^{2+} . \mathrm{Mg}_{\mathrm{i}}^{2+}$ was quantitated over $2 \mathrm{~h}$. Each data point represents the mean $\mathrm{Mg}_{\mathrm{i}}^{2+}$ of 30 individual cells from each of three experiments.

Figure 8. GDC increases $\mathrm{Mg}_{\mathrm{i}}^{2+} . \mathrm{Mg}_{\mathrm{i}}^{2+}$ in individual Mag-Fura-2-loaded cells was monitored by ratio imaging of MagFura-2 fluorescence using digitized video microscopy. Cells were incubated in the absence of GDC, but in the presence of $1.4 \mathrm{mM}$ extracellular $\mathrm{Mg}^{2+}$ (Control, closed squares) or in the pressquares) or in the pres西

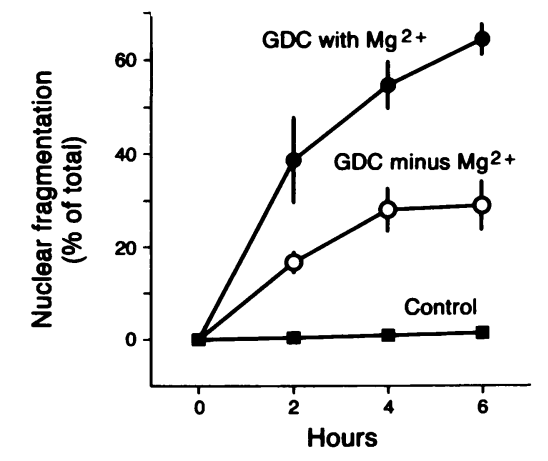
cellular $\mathrm{Mg}^{2+}$. At least 300 cells in 4 high-power fields were counted. Nuclear fragmentation represents cells with at least three nuclear fragments expressed as a percentage of total cells counted.

Figure 9. Removal of extracellular magnesium reduces GDC-induced nuclear fragmentation. Cells were incubated in the absence of GDC, but in the presence of 1.4 $\mathrm{mM}$ extracellular $\mathrm{Mg}^{2+}$ (Control, closed squares) or in the presence of $50 \mu \mathrm{M}$ GDC with (closed circles) or without (open circles) extra- 


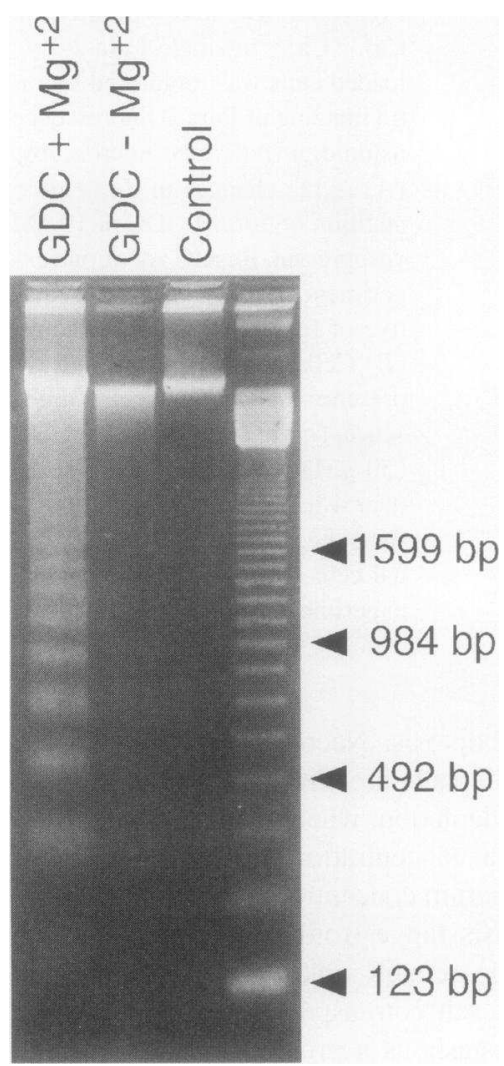
treated with GDC in the presence of extracellular $\mathrm{Mg}^{2+}$ but not in controls or GDC-treated cells cultured in $\mathrm{Mg}^{2+}$-free medium.

apoptosis are increasingly being appreciated (49). For example, cytotoxic anticancer drugs have been shown to cause apoptosis in target cells $(49,50)$. Our data demonstrating apoptosis by a toxic bile salt are consistent with the concept of toxin-induced apoptosis.

The frequent presence of internucleosomal DNA cleavage in apoptotic cells suggests that endonuclease activation is a common mechanism in the program of events culminating in apoptosis (10). Furthermore, as observed in the current study, inhibitors of endonucleases such as zinc often prevent both the DNA fragmentation and the morphologic features of apoptosis, further suggesting a mechanistic role for endonucleases in apoptosis (11). Understanding the regulation of endonuclease activity is an important step in elucidating the cellular mechanisms of apoptosis. Current efforts elucidating the cellular mechanism regulating endonuclease activity have focused on macromolecular synthesis and ion regulation (i.e., $\mathrm{Ca}^{2+}$ and $\mathrm{pH})(11,51)$. In our studies, inhibitors of translation and transcription did not prevent apoptosis as has been observed in other models of toxin-induced apoptosis $(11,50)$. The inability of inhibitors of translation and transcription to prevent apoptosis is also consistent with several observations identifying constitutive nuclear endonuclease activity in hepatocytes (39). Several endonucleases have been isolated and postulated to play a role during apoptosis such as the $\mathrm{Ca}^{2+} \mathrm{Mg}^{2+}$-dependent endonuclease from human spleen, the $\mathrm{Ca}^{2+}$-dependent deoxyribonuclease I from rat thymocyte and lymph nodes, and the $\mathrm{pH}$-sensitive deoxyribonuclease II from Chinese hamster ovary cells (5254). Although these endonucleases are regulated by changes in $\mathrm{Ca}_{\mathrm{i}}^{2+}, \mathrm{Mg}_{\mathrm{i}}^{2+}$, or $\mathrm{pH}_{\mathrm{i}}$, changes in $\mathrm{Ca}_{\mathrm{i}}^{2+}$ or $\mathrm{pH}$ were not ob- served during GDC-induced hepatocyte apoptosis. An $\mathrm{Mg}^{2+}$ dependent endonuclease has been described in rat liver nuclei (55). Because endonucleases in many cells types require $\mathrm{Mg}^{2+}$ for activity, we determined the in vitro $\mathrm{Mg}^{2+}$ dependence of rat hepatocyte endonuclease activity and measured $\mathbf{M g}_{\mathrm{i}}^{2+}$ in hepatocytes undergoing apoptosis by GDC. Curiously, although endonucleases are known to be $\mathbf{M g}^{2+}$-dependent, measurements of $\mathrm{Mg}_{\mathrm{i}}^{2+}$ have not been previously performed during apoptosis. We found that in vitro endonuclease activity present in soluble protein extracts from rat hepatocyte nuclei was predominantly $\mathrm{Mg}^{2+}$ dependent. Addition of GDC to the in vitro assay did not increase endonuclease activity, demonstrating that GDC does not directly stimulate endonucleases. Likewise, there was no difference in the magnitude or cation dependence of endonuclease activity isolated from cells treated with GDC. During treatment of hepatocytes with GDC, $\mathrm{Mg}_{\mathrm{i}}^{2+}$ increased twofold and incubation of cells in an $\mathrm{Mg}^{2+}$-free medium prevented the rise in $\mathrm{Mg}_{\mathrm{i}}^{2+}$ and reduced nuclear and DNA fragmentation. These observations suggest that GDC induces apoptosis in hepatocytes by a mechanism promoted by increases of $\mathrm{Mg}_{\mathrm{i}}^{2+}$. The increase of $\mathrm{Mg}_{\mathrm{i}}^{2+}$ may lead to DNA fragmentation by stimulating $\mathrm{Mg}^{2+}$ dependent endonuclease activity or by altering DNA/protein interactions, rendering the DNA more susceptible to endonuclease cleavage. Although removal of extracellular $\mathrm{Mg}^{2+}$ prevented the rise in $\mathrm{Mg}_{\mathrm{i}}^{2+}$, this maneuver did not lower basal concentrations of $\mathrm{Mg}^{2+}$ or completely block nuclear fragmentation. These observations suggest that the rate of apoptosis may be dependent upon the concentration of $\mathrm{Mg}^{2+}$, with lower rates at physiologic concentrations of $\mathrm{Mg}^{2+}$ and higher rates at higher concentrations of $\mathrm{Mg}_{\mathrm{i}}^{2+}$

The increase of $\mathrm{Mg}_{\mathrm{i}}^{2+}$ during GDC-induced apoptosis could arise from the release of $\mathrm{Mg}^{2+}$ from intracellular stores or from an influx of extracellular $\mathbf{M g}^{2+}$ into the cell. In hepatocytes, the vast majority of intracellular $\mathbf{M g}^{2+}$ is bound to ATP or intracellular nondiffusible binding sites (45). Hydrolysis of ATP releases $\mathrm{Mg}^{2+}$ from the ATP $/ \mathrm{Mg}^{2+}$ complex, causing a rise in $\mathrm{Mg}_{\mathrm{i}}^{2+}(37,56)$, and toxic bile salts can inhibit mitochondrial ATP synthesis, resulting in net hydrolysis of ATP (23). However, in our studies, there was minimal loss of ATP during GDC-induced apoptosis, suggesting that the rise of $\mathrm{Mg}_{\mathrm{i}}^{2+}$ was not caused by ATP hydrolysis. Preservation of cellular ATP during the active process of cell death by apoptosis has been a consistent finding in the literature, and in some models ATP depletion may actually inhibit apoptosis (57). Removal of extracellular $\mathrm{Mg}^{2+}$ inhibited the rise of $\mathrm{Mg}^{2+}$ during hepatocyte apoptosis by GDC, an observation suggesting that an influx of extracellular $\mathrm{Mg}^{2+}$ into the cell was responsible for the rise of $\mathrm{Mg}_{\mathrm{i}}^{2+}$. The mechanism of $\mathrm{Mg}^{2+}$ entry into the cell was not elucidated by these studies. However, DC conjugates have been demonstrated to increase cation currents in a colonic cell line ( T84 cells) (22). Opening of a cation conductance channel may permit an influx of extracellular $\mathbf{M g}^{2+}$ down its concentration gradient, causing an increase of $\mathbf{M g}_{\mathrm{i}}^{2+}$. Electrophysiologic studies will be required to determine if GDC stimulates opening of these channels in hepatocytes and the relative permeability and selectivity of these channels for $\mathrm{Mg}^{2+}$. A direct physicochemical interaction of GDC with the plasma membrane increasing $\mathrm{Mg}^{2+}$ permeability is also a highly plausible explanation for the influx of $\mathrm{Mg}^{2+}$ into the cell.

In our studies, GDC-induced apoptosis was not associated with increases of $\mathrm{Ca}_{i}^{2+}$. Although increases of $\mathrm{Ca}_{\mathrm{i}}^{2+}$ have been 
associated with apoptosis in immature thymocytes, lymphocytes, and mammary adenocarcinoma cells, $\mathrm{Ca}^{2+}$ is not required for apoptosis in human leukemia cells $(11,58,59)$. Moreover, elevations of $\mathrm{Ca}_{i}^{2+}$ actually retard the development of apoptosis in neutrophils (60). Thus, increases in $\mathrm{Ca}^{2+}$ are not a universal requirement for apoptosis. The role of $\mathrm{Ca}_{\mathrm{i}}^{2+}$ in apoptosis may vary between cell types and the mechanism of apoptosis induction within a given cell type. Additional studies will be required to determine if increases of $\mathrm{Ca}_{\mathrm{i}}^{2+}$ can participate as a mechanism of apoptosis in hepatocytes. Although concentrations of deoxycholates of $>500 \mu \mathrm{M}$ cause increases of $\mathrm{Ca}_{\mathrm{i}}^{2+}$ in hepatocytes, lower concentrations have not been associated with increases of $\mathrm{Ca}_{i}^{2+}(20)$. Our studies demonstrating that $50 \mu \mathrm{M}$ GDC did not cause an increase of $\mathrm{Ca}_{\mathrm{i}}^{2+}$ are consistent with these previous observations.

The greater toxicity of GDC compared with DC or TDC is consistent with several observations demonstrating that the glycine conjugates are the most toxic species of hydrophobic bile salts $(61,62)$. In human bile and presumably in the hepatocyte, bile salts are $>95 \%$ conjugated to glycine or taurine with an approximate glycine/taurine ratio of 1.8:1 (63). Thus, our finding that GDC is the most toxic species of DC is physiologically relevant, suggesting bile salt-induced apoptosis may play an important role in human cholestatic liver disease.

Our working hypothesis is that GDC-induced apoptosis is promoted by an influx of $\mathrm{Mg}^{2+}$ into the cell, stimulating activity of nuclear endonucleases. The activation of endonucleases with DNA cleavage is the cytotoxic trigger producing apoptosis. The hypothesis is supported by the observation that removal of extracellular $\mathrm{Mg}^{2+}$ prevents the rise in $\mathrm{Mg}_{\mathrm{i}}^{2+}$ and the morphologic and biochemical features of apoptosis. The $\mathrm{Mg}^{2+}$ dependence of hepatocyte, nuclear endonuclease activity also supports this hypothesis. Further information on the yet to be identified endonuclease responsible for DNA fragmentation during hepatocyte apoptosis will be required to fully clarify the mechanism of GDC-induced apoptosis. Finally, our data suggesting a role for $\mathrm{Mg}_{\mathrm{i}}^{2+}$ in the program of events culminating in apoptosis may provide useful insight into mechanisms of apoptosis in other cell types during physiologic and pathophysiologic conditions.

\section{Acknowledgments}

The secretarial assistance of Sara Erickson is gratefully acknowledged.

This work was supported by the Mayo Foundation, the Gainey Foundation, grant DK-41876 from the National Institutes of Health (G. J. Gores), and by an AGA Foundation/Merck Senior Research Fellow Award (T. Patel).

\section{References}

1. Greim, H., D. Trulzsch, P. Czygan, J. Rudick, F. Hutterer, F. Schaffner, and H. Popper. 1972. Mechanism of cholestasis. VI. Bile acids in human livers with or without biliary obstruction. Gastroenterology. 63:846-850.

2. Greim, H., D. Trulzsch, J. Roboz, K. Dressler, P. Czygan, F. Hutterer, F. Schaffner, and H. Popper. 1972. Mechanism of cholestasis. V. Bile acids in normal rat livers and in those after bile duct ligation human livers with or without biliary obstruction. Gastroenterology. 63:837-845.

3. Heuman, D. M., A. S. Mills, J. B. McCall, P. B. Hylemon, W. M. Pandak, and Z. R. Vlahcevic. 1991. Conjugates of ursodeoxycholate protect against cholestasis and hepatocellular necrosis caused by more hydrophobic bile salts: in vivo studies in the rat. Gastroenterology. 100:203-211.

4. Heuman, D. M. 1993. Hepatoprotective properties of ursodeoxycholic acid. Gastroenterology. 104:1865-1870.

5. Attili, A. F., M. Angelico, A. Cantafora, D. Alvaro, and L. Capocaccia.
1986. Bile acid-induced liver toxicity: relation to the hydrophobic-hydrophilic balance of bile acids. Med. Hypotheses 19:57-69.

6. Zimniak, P., J. M. Little, A. Radominska, D. G. Oelberg, M. S. Anwer, and R. Lester. 1991. Taurine-conjugated bile acids act as calcium ionophores. Biochemistry. 30:8598-8604.

7. Anwer, M. S., L. R. Engelking, K. Nolan, D. Sullivan, P. Zimniak, and R. Lester. 1991. Hepatotoxic bile acids increase cytosolic calcium activity of isolated rat hepatocytes. Hepatology. 8:887-891.

8. Searle, J., B. V. Harmon, C. J. Bishop, and J. F. R. Kerr. 1987. The significance of cell death by apoptosis in hepatobiliary disease. J. Gastroenterol. Hepatol. 2:77-96.

9. Oberhammer, F., J. W. Wilson, C. Dive, I. D. Morris, J. A. Hickman, A. E. Wakeling, P. Roy Walker, and M. Sikorska. 1993. Apoptotic death in epithelial cells: cleavage of DNA to 300 and/or $50 \mathrm{~kb}$ fragments prior to or in the absence of internucleosomal fragmentation. EMBO (Eur. Mol. Biol. Organ.) J. 12:36793684 .

10. Compton, M. M. 1992. A biochemical hallmark of apoptosis: internucleosomal degradation of the genome. Cancer Metastasis Rev. 11:105-119.

11. Schwartzman, R., and J. Cidlowski. 1993. Apoptosis: the biochemistry and molecular biology of programmed cell death. Endocr. Rev. 14:133-151.

12. Columbano, A., G. M. Ledda-Columbano, P. P. Coni, G. Faa, C. Liguori, G. SantaCruz, and P. Pani. 1985. Occurrence of cell death (apoptosis) during the involution of liver hyperplasia. Lab. Invest. 52:670-675.

13. Reynolds, E. S., M. F. Kanz, P. Chieco, and M. T. Moslen. 1984. 1,1Dichloroethylene: an apoptotic hepatotoxin? Environ. Health Perspect. 57:313320 .

14. Pritchard, D. J., and W. H. Butler. 1989. Apoptosis: the mechanism of cell death in dimethylnitrosamine-induced hepatotoxicity. J. Pathol. 158:253260.

15. Evans, D. L., and C. Dive. 1993. Effects of cisplatin on the induction of apoptosis in proliferating hepatoma cells and nonproliferating immature thymocytes. Cancer Res. 53:2133-2139.

16. VanderNeer, R., D. Termont, and H. DeVries. 1991. Differential effects of calcium ions and calcium phosphate on cytotoxicity of bile acids. Am. J. Physiol. 260:G142-G147.

17. Vlahcevic, Z. R., D. M. Heuman, and P. B. Hyleman. 1990. Physiology and pathophysiology of enterohepatic circulation of bile salts. In Hepatology: A Textbook of Liver Disease. D. Zakim and T. D. Boyer, editors. W. B. Saunders Co., Philadelphia. 341-377.

18. Beuers, U., U. Spengler, F. Zwiebel, J. Pauletzki, and S. Fisher. 1992. Effect of ursodeoxycholic acid on the kinetics of the major hydrophobic bile acids in health and in chronic cholestatic liver disease. Hepatology. 15:603-608.

19. Kandell, R. L., and C. Bernstein. 1991. Bile salt/acid induction of DNA damage in bacterial and mammalian cells: implications for colon cancer. Nutr. Cancer. 16:227-238.

20. Anwer, M. S., L. Engelking, K. Nolan, D. Sullivan, P. Zimniak, and R. Lester. 1988. Hepatotoxic bile acids increase cytosolic calcium activity of isolated rat hepatocytes. Hepatology. 8:887-891.

21. McConkey, D. J., P. Nicotera, P. Hartzell, G. Bellomo, A. Wyllie, and S. Orrenius. 1989. Glucocorticoids activate a suicide process in thymocytes through an elevation of cytosolic $\mathrm{Ca}^{++}$concentration. Arch. Biochem. Biophys. 269:365370 .

22. Devor, D. C., M. C. Sekar, R. A. Frizzell, and M. E. Duffey. 1993. Taurodeoxycholate activates potassium and chloride conductances via an $\mathrm{IP}_{3^{-}}$ mediated release of calcium from intracellular stores in a colonic cell line (T84). J. Clin. Invest. 92:2173-2181.

23. Spivey, J. R., S. F. Bronk, and G. J. Gores. 1993. Glycochenodeoxycholateinduced lethal hepatocellular injury in rat hepatocytes. Role of ATP depletion and cytosolic free calcium. J. Clin. Invest. 92:17-24.

24. Gores, G. J., A.-L. Nieminen, B. E. Wray, B. Herman, and J. J. Lemasters. 1989. Intracellular $\mathrm{pH}$ during "chemical hypoxia" in cultured rat hepatocytes. Protection by intracellular acidosis against onset of cell death. J. Clin. Invest. 83:386-396.

25. Frimmer, M., and K. Ziegler. 1988. The transport of bile acids in liver cells. Biochim. Biophys. Acta. 847:74-79.

26. Liang, D., B. Hagenbuch, B. Stieger, and P. Meier. 1993. Parallel decrease of $\mathrm{Na}^{+}$-taurocholate cotransport and its encoding mRNA in primary cultures of rat hepatocytes. Hepatology. 18:1162-1166.

27. Groskreutz, J. L., S. F. Bronk, and G. J. Gores. 1992. Ruthenium red delays the onset of cell death during oxidative stress of rat hepatocytes. Gastroenterology. 102:1030-1038

28. Oberhammer, F. A., M. Pavelka, S. Sharma, R. Tiefenbacher, A. F. Purchio, W. Bursch, and R. Schulte-Hermann. 1992. Induction of apoptosis in cultured hepatocytes and in regressing liver by transforming growth factor $\beta 1$. Proc. Natl. Acad. Sci. USA. 89:5408-5412.

29. Bellomo, G., M. Perotti, F. Taddei, F. Mirabelli, G. Finardi, P. Nicotera, and S. Orrenius. 1992. Tumor necrosis factor alpha induces apoptosis in mammary adenocarcinoma cells by an increase in intranuclear free $\mathrm{Ca}^{++}$concentration and DNA fragmentation. Cancer Res. 52:1342-1346.

30. Nicoletti, I., G. Migliorati, M. C. Pagliacci, F. Grignani, and C. Riccardi. 
1991. A rapid and simple method for measuring thymocyte apoptosis by propidium iodide staining and flow cytometry. J. Immunol. Methods. 139:271-279.

31. Dickson, R. C., S. F. Bronk, and G. J. Gores. 1992. Glycine cytoprotection during lethal hepatocellular injury from adenosine triphosphate depletion. Gastroenterology. 102:2098-2107.

32. McDowell, E. M., and B. Trump. 1976. Histologic fixatives suitable for diagnostic light and electron microscopy. Arch. Pathol. Lab. Med. 100:405-414.

33. Spurr, A. R. 1969. A low-viscosity epoxy resin embedding medium for electron microscopy. J. Ultrastruct. Res. 26:31-43.

34. Wyllie, A. H. 1980. Glucocorticoid-induced thymocyte apoptosis is associated with endogenous endonuclease activation. Nature (Lond.). 284:555-556.

35. Richards, G. M. 1974. Modifications of the diphenylamine reaction giving increased sensitivity and simplicity in the estimation of DNA. Anal. Biochem. 57:369-376.

36. Sambrook, J., E. F. Fritsch, and T. Maniatis. 1989. Molecular Cloning: A Laboratory Manual. 2nd ed. Cold Spring Harbor Laboratory, Cold Spring Harbor, NY. 6.9-6.12.

37. Raju, B., E. Murphy, L. A. Levy, R. D. Hall, and R. E. London. 1989. A fluorescent indicator for measuring cytosolic free magnesium. Am. J. Physiol. 256:C540-C548.

38. Grynkiewicz, G., M. Poenie, and R. Y. Tsien. 1985. A new generation of calcium indicators with greatly improved fluorescence properties. J. Biol. Chem. 260:3440-3450.

39. Schwartzman, R. A., and J. A. Cidlowski. 1993. Mechanism of tissuespecific induction of internucleosomal deoxyribonucleic acid cleavage activity and apoptosis by glucocorticoids. Endocrinology. 133:591-599.

40. Undenfried, S. S. Stein, P. Bohlen, and W. Dairman. 1972. Fluorescamine: a reagent for assay of amino acids. Science (Wash. DC). 178:871-872.

41. Yonemura, K., and H. Maeda. 1982. A new assay method for DNAse by fluorescence polarization and fluorescence intensity using DNA-ethidium bromide complex as a sensitive substrate. J. Biochem. 92:1297-1303.

42. Roda, A., G. Cappelleri, R. Aldini, E. Roda, and L. Barbara. 1982. Quantitative aspects of the interaction of bile acids with human serum albumin. J. Lipid Res. 23:490-495.

43. McConkey, D. J., P. Hartzell, P. Nicotera, A. H. Wyllie, and S. Orrenius. 1988. Stimulation of endogenous endonuclease activity in hepatocytes exposed to oxidative stress. Toxicol. Lett. (Amst.). 42:123-130.

44. Hewish, D. R., and L. A. Burgoyne. 1973. The calcium dependent endonuclease activity of isolated nuclear preparations. Relationship between its occurrence and the occurrence of other classes of enzymes found in nuclear preparations. Biochem. Biophys. Res. Commun. 52:475-481.

45. Corkey, B. E., J. Duszynski, T. L. Rich, B. Matschinsky, and J. R. Williamson. 1986. Regulation of free and bound magnesium in rat hepatocytes and isolated mitochondria. J. Biol. Chem. 261:2567-2574.

46. Raedsch, R., G. H. Lauterburg, and A. F. Hoffmann. 1981. Altered bile acid metabolism in primary biliary cirrhosis. Dig. Dis. Sci. 26:395-400.

47. Gartung, C., M. Ananthanarayanan, M. A. Rahman, A. Stolz, F. J. Suchy, and J. L. Boyer. 1993. Cholestasis induces down-regulation of the sodium depen- dent bile acid co-transporter and cytosolic binding proteins following bile duct ligation in the rat. Hepatology. 18:139a. (Abstr.)

48. Arends, M., and A. Wyllie. 1991. Apoptosis: mechanisms and roles in pathology. Int. Rev. Exp. Pathol. 32:223-254.

49. Gerschenson, L. E., and R. J. Rotello. 1992. Apoptosis: a different type of cell death. FASEB (Fed. Am. Soc. Exp. Biol.) J. 6:2450-2455.

50. Martin, S. J., and T. G. Cotter. 1994. Apoptosis of human leukemia: induction, morphology, and molecular mechanisms. In Apoptosis II: The Molecular Basis of Apoptosis in Disease. Cold Spring Harbor Laboratory, Cold Spring Harbor, NY. 185-230.

51. Barry, M. A., and A. Eastman. 1992. Endonuclease activation during apoptosis: the role of cytosolic calcium and pH. Biochem. Biophys. Res. Commun. 186:782-789.

52. Ribeiro, J. M., and D. A. Carson. 1993. $\mathrm{Ca}^{2+} / \mathrm{Mg}^{2+}$-dependent endonuclease from human spleen: purification, properties, and role in apoptosis. Biochemistry. 32:9129-9136.

53. Barry, M. A., and A. Eastman. 1993. Identification of deoxyribonuclease II as an endonuclease involved in apoptosis. Arch. Biochem. Biophys. 300:440450.

54. Peitsch, M. C., B. Polzar, H. Stephan, T. Crompton, H. R. MacDonald, H. G. Mannherz, and J. Tschopp. 1993. Characterization of the endogenous deoxyribonuclease involved in nuclear DNA degradation during apoptosis (programmed cell death). EMBO (Eur. Mol. Biol. Organ.) J. 12:371-377.

55. Hibino, Y., T. Yoneda, and N. Sugano. 1988. Purification and properties of a magnesium-dependent endodeoxyribonuclease endogenous to rat liver nuclei. Biochim. Biophys. Acta. 950:313-320.

56. Harman, A. W., A. L. Nieminen, J. J. Lemasters, and B. Herman. 1990. Cytosolic free magnesium, ATP, and blebbing during chemical hypoxia in cultured rat hepatocytes. Biochem. Biophys. Res. Commun. 170:477-483.

57. Thakkar, N. S., and C. S. Potten. 1993. Inhibition of doxorubicin-induced apoptosis in vivo by 2-deoxy-D-glucose. Cancer Res. 53:2057-2060.

58. Trump, B. F., and I. K. Berezesky. 1992. The role of cytosolic $\mathrm{Ca}^{++}$in cell injury, necrosis and apoptosis. Curr. Opin. Cell Biol. 4:227-232.

59. Lennon, S. V., S. A. Kilfeather, M. B. Hallett, A. K. Campbell, and T. J. Cotter. 1992. Elevations in cytosolic free calcium are not required to trigger apoptosis in human leukemia cells. Clin. Exp. Immunol. 87:465-471.

60. Whyte, M. K. B., S. J. Hardwick, L. C. Meagher, J. S. Savill, and C. Haslett. 1993. Transient elevations of cytosolic free calcium retard subsequent apoptosis in neutrophils in vivo. J. Clin. Invest. 92:446-455.

61. Scholmerich, J., M. Becher, K. Schmidt, R. Schubert, and B. Kremer. 1984. Influence of hydroxylation and conjugation of bile salts on their membrane damaging properties: studies on isolated hepatocytes and lipid membrane vesicles. Hepatology. 4:661-666.

62. Kimura, T. 1980. Cytotoxicity of bile acids on cultured cells. Nippon Shokakibyo Gakkai Zasshi. 77:185-194.

63. Crosigagni, A., M. Podda, P. M. Battezzati, E. Bertolini, M. Zuin, D Watson, and K. D. R. Setchell. 1991. Changes in bile acid composition in patients with primary biliary cirrhosis induced by ursodeoxycholic acid administration. Hepatology. 14:1000-1007. 